\title{
Effect of boron on growth, nutrition and fertility status of large cardamom in Sikkim Himalaya, India
}

\author{
B.A. Gudade ${ }^{1 *}$, Subhash Babu ${ }^{2}$, S.S. Bora ${ }^{1}$, K. Dhanapal ${ }^{1}$ and Raghavendra Singh ${ }^{2}$ \\ ${ }^{1}$ Division of Agronomy, ICRI, RRS, Spices Board, Tadong, Gangtok-737102 (Sikkim), INDIA \\ ${ }^{2}$ Division of Agronomy, ICAR, RC, NEH Region, Sikkim Centre, Gangtok-737102 (Sikkim), INDIA \\ *Corresponding author. E-mail: bgudade@gmail.com \\ Received: July 22, 2015; Revised received: February 4, 2016; Accepted: May 19, 2016
}

\begin{abstract}
Field experiment was conducted at Indian Cardamom Research Institute, Regional Research Station, Spices Board Kabi research farm North Sikkim to find out the effect of Boron nutrition on growth, nutrient content and soil fertility status of large cardamom. The experiment was laid out in RBD comprising seven treatments $\left(T_{1}\right.$ soil application of borax@2.5 kg ha ${ }^{-1}, \mathrm{~T}_{2}$ soil application of borax@5.0 kg ha- $\mathrm{k}_{3}$ foliar application of borax@0.25\%, T 4 foliar application of borax @0.5\%, $\mathrm{T}_{5}$ foliar application of borax@0.25\%+ soil application of borax@2.5 kg ha-1, $\mathrm{T}_{6}$ foliar application of borax@0.5\%+ soil application of borax@2.5 $\mathrm{kg} \mathrm{ha}^{-1}$ and $\mathrm{T}_{7}$ control). Results reveal that foliar application of borax@0.5\%+ soil application of borax@2.5 kg ha ${ }^{-1}$ recorded the maximum values of immature tillers per clump (2.98 and 3.95) and mature tillers per clump (2.99 and 3.11) during both September, 2013 and March, 2014 and vegetative buds per clump (2.90). With regards to nutrient content in leaf of large cardamom among the treatments, foliar application of borax@0.5\%+soil application of borax@2.5 kg ha-1 recorded highest nutrient acquisition However, its effect was statistically non significant on $\mathrm{K}, \mathrm{S}, \mathrm{Ca}, \mathrm{Zn}, \mathrm{Cu}, \mathrm{Mn}$ and Fe content and significant on N(2.59\%), P (0.18\%), Mg (0.39\%) and B (15.45 ppm) content in leaf.
\end{abstract}

Keywords: Boron, Growth parameters, Large cardamom, Nutrient content, Sikkim

\section{INTRODUCTION}

Large cardamom (Amomum subulatum Roxburgh), belonging to family Zingiberaceae cultivated in Sikkim Himalayan region since time of immemorial and is believed that large cardamom is the native of the state. It is popularly known as bada elaichi in Hindi alainchi in Nepali is one of the World's ancient spices. Sikkim is the largest producer of large cardamom, constituting lion share of the Indian and world market (Gudade et al., 2013a). It is a shade loving plant (Sciophyte) and grown in the tracks up to 1000 to $2200 \mathrm{~m}$ above mean sea level with well distributed rainfall spread around 200 days with a total of about 3000-3500 mm/year (Gudade et al., 2013b). It is essentially a crosspollinated crop due to the heterostylic nature of its flowers, though they are self fertile. Bumble bee is the major pollinator in large cardamom due to its high pollination efficiency attributed to its big body size, foraging habit (Deka et al., 2014). In recent year's productivity of large cardamom declined in Sikkim (Gudade et al., 2015). There are several factors culprit for declination of productivity. Among the various reasons for low productivity, one finds the role of plant nutrients especially micronutrients of paramount importance. There is ample scope of increasing production by use of good agronomic practices as well as proper fertility management. Soil fertility is an important factor, which determines the growth of plant. Micronutrients increase plant productivity, leaf and grain yield. Most of the micronutrients are associated with the enzymatic system of plants. Whenever a micronutrient is deficient the abnormal growth of plant results which sometime cause complete failure of crops. Grains and flower formation does not take place in severe deficiency. The main sources of these micronutrients are parent material, sewage sludge, town refuse, farmyard manure (FYM) and organic matter. These nutrients are present in small amounts ranging from few mg kg-1 to several thousand $\mathrm{mg} \mathrm{kg}^{-1}$ in soils (Wajahat et al., 2006). Boron deficiency is reported from the North Eastern States of India (Prasad, 2012). Among the micronutrients Boron is a micronutrient of special importance because of its role in the fertilization and flowering process. It also plays an essential role in the growth and development of new cells in the plant meristem. Facilitating pollination and fruit set is considered to be the most important function of boron besides its role in the synthesis of amino acids and protein metabolism. Application of boron (B) has received a great deal of importance in high responsive oil seed crops during the last few years, because of widespread occurrence of deficiency from different parts of India. Significant response of oil seed crops to the application of boron containing fertilizers have also been reported (Chakraborty and Das, 2000; Mandal et 
al., 2009). Boron is absorbed by roots as un-dissociated boric acid $\left[\mathrm{B}(\mathrm{OH})_{3}\right.$ or $\left.\mathrm{H}_{3} \mathrm{BO}_{3}\right]$ which has a strong ability to form complexes with diols and polyols, particularly with cis-diols inside the plant system (Loomis and Durst, 1992). Among the elements required by plants that are taken up from the soil, B is the only element that is taken up by plants not as an ion, but as an uncharged molecule (Miwa and Fujiwara, 2010). The factors affecting B uptake include soil type (texture, alkalinity/calcareousness,

Table 1. Effect of boron application on growth components of large cardamom.

\begin{tabular}{llllll}
\hline \multirow{2}{*}{ Treatments } & \multicolumn{2}{c}{ Immature tillers/clump } & \multicolumn{2}{c}{ Mature tillers/clump } & Vegetative buds/ \\
clump Mar. 2014
\end{tabular}

$\mathrm{SA}=$ Soil Application; FA= Foliar Application; Source of Boron= Borax

Table 2. Effect of boron application on nutrient content in leaf of large cardamom.

\begin{tabular}{|c|c|c|c|c|c|c|}
\hline \multirow{2}{*}{ Treatments } & \multicolumn{6}{|c|}{ Nutrient Content (\%) } \\
\hline & $\mathbf{N}$ & $\mathbf{P}$ & $\mathbf{K}$ & $\mathbf{C a}$ & Mg & $\mathbf{S}$ \\
\hline SA of B@ $2.5 \mathrm{~kg} \mathrm{ha}^{-1}$ & 2.25 & 0.134 & 1.44 & 0.48 & 0.32 & 0.140 \\
\hline $\mathrm{SA}$ of B@5.0 kg ha ${ }^{-1}$ & 2.38 & 0.151 & 1.47 & 0.47 & 0.34 & 0.141 \\
\hline FA of B@0.25\% & 2.45 & 0.153 & 1.49 & 0.46 & 0.31 & 0.140 \\
\hline FA of B@ $0.5 \%$ & 2.45 & 0.162 & 1.47 & 0.47 & 0.34 & 0.142 \\
\hline FA of B@ $0.25 \%+\mathrm{SA}$ of B@ $2.5 \mathrm{~kg} \mathrm{ha}^{-1}$ & 2.47 & 0.172 & 1.56 & 0.58 & 0.37 & 0.143 \\
\hline FA of B@ $0.5 \%+$ SA of B@ $2.5 \mathrm{~kg} \mathrm{ha}^{-1}$ & 2.59 & 0.180 & 1.63 & 0.61 & 0.39 & 0.145 \\
\hline Control & 2.10 & 0.121 & 1.45 & 0.43 & 0.29 & 0.138 \\
\hline $\mathrm{SEm} \pm$ & 0.13 & 0.01 & 0.22 & 0.07 & 0.02 & 0.008 \\
\hline $\operatorname{LSD}(\mathrm{P}=0.05)$ & 0.33 & 0.03 & NS & NS & 0.06 & NS \\
\hline
\end{tabular}

$\mathrm{SA}=$ Soil Application; FA= Foliar Application; Source of Boron= Borax

Table 3. Effect of boron application on nutrient content in leaf of large cardamom.

\begin{tabular}{|c|c|c|c|c|c|}
\hline \multirow{2}{*}{ Treatments } & \multicolumn{5}{|c|}{ Nutrient Content (ppm) } \\
\hline & $\mathbf{Z n}$ & $\mathbf{C u}$ & Mn & $\mathbf{F e}$ & $\mathbf{B}$ \\
\hline SA of B@ $2.5 \mathrm{~kg} \mathrm{ha}^{-1}$ & 32.17 & 4.60 & 535.3 & 309.2 & 12.30 \\
\hline $\mathrm{SA}$ of B@ $5.0 \mathrm{~kg} \mathrm{ha}^{-1}$ & 32.89 & 6.60 & 586.0 & 318.1 & 12.56 \\
\hline FA of B@ $0.25 \%$ & 35.09 & 6.00 & 523.6 & 359.3 & 11.57 \\
\hline FA of B@ $0.5 \%$ & 33.47 & 6.90 & 513.7 & 319.9 & 11.55 \\
\hline FA of B@ $0.25 \%+S A$ of B@ $2.5 \mathrm{~kg} \mathrm{ha}^{-1}$ & 36.07 & 6.30 & 508.4 & 321.1 & 14.75 \\
\hline FA of B@ $0.5 \%+S A$ of B@ $2.5 \mathrm{~kg} \mathrm{ha}^{-1}$ & 37.56 & 5.49 & 500.2 & 319.6 & 15.45 \\
\hline Control & 34.02 & 5.60 & 597.0 & 351.7 & 10.80 \\
\hline $\mathrm{SEm} \pm$ & 1.79 & 0.97 & 38.69 & 19.08 & 0.802 \\
\hline $\operatorname{LSD}(\mathrm{P}=0.05)$ & $\mathrm{NS}$ & NS & NS & NS & 2.022 \\
\hline
\end{tabular}

$\mathrm{SA}=$ Soil Application; FA= Foliar Application; Source of Boron= Borax

Table 4. Effect of boron application on soil fertility status of Kabi, North Sikkim.

\begin{tabular}{|c|c|c|c|c|c|c|c|c|}
\hline \multirow{2}{*}{ Treatments } & \multicolumn{8}{|c|}{ Available nutrients (ppm) } \\
\hline & $\mathbf{C a}$ & $\mathbf{M g}$ & $\mathbf{S}$ & $\mathbf{Z n}$ & $\mathbf{C u}$ & Mn & $\mathbf{F e}$ & $\mathbf{B}$ \\
\hline SA of B $@ 2.5 \mathrm{~kg} \mathrm{ha}^{-1}$ & 128 & 22.33 & 4.03 & 2.89 & 2.17 & 13.06 & 49.32 & 0.173 \\
\hline SA of B@ $5.0 \mathrm{~kg} \mathrm{ha}^{-1}$ & 133 & 23.67 & 4.33 & 3.01 & 2.21 & 15.23 & 48.67 & 0.187 \\
\hline FA of B@0.25\% & 135 & 21.57 & 3.90 & 2.82 & 2.11 & 13.80 & 52.06 & 0.123 \\
\hline FA of B@ $0.5 \%$ & 141 & 21.92 & 3.97 & 2.87 & 2.09 & 13.00 & 54.32 & 0.107 \\
\hline FA of B@ $0.25 \%+\mathrm{SA}$ of $\mathrm{B} @ 2.5 \mathrm{~kg} \mathrm{ha}^{-1}$ & 161 & 22.33 & 4.35 & 2.92 & 2.24 & 16.43 & 57.49 & 0.240 \\
\hline FA of B@ $0.5 \%+$ SA of B@ $2.5 \mathrm{~kg} \mathrm{ha}^{-1}$ & 170 & 23.69 & 4.72 & 2.95 & 2.33 & 17.11 & 59.84 & 0.257 \\
\hline Control & 125 & 22.00 & 3.97 & 2.80 & 2.19 & 14.08 & 50.77 & 0.097 \\
\hline $\mathrm{SEm} \pm$ & 18.2 & 2.15 & 0.312 & 0.213 & 0.181 & 3.25 & 4.89 & 0.006 \\
\hline $\operatorname{LSD}(\mathrm{P}=0.05)$ & NS & NS & NS & NS & NS & NS & NS & 0.016 \\
\hline
\end{tabular}

$\mathrm{SA}=$ Soil Application; FA= Foliar Application; Source of Boron= Borax 


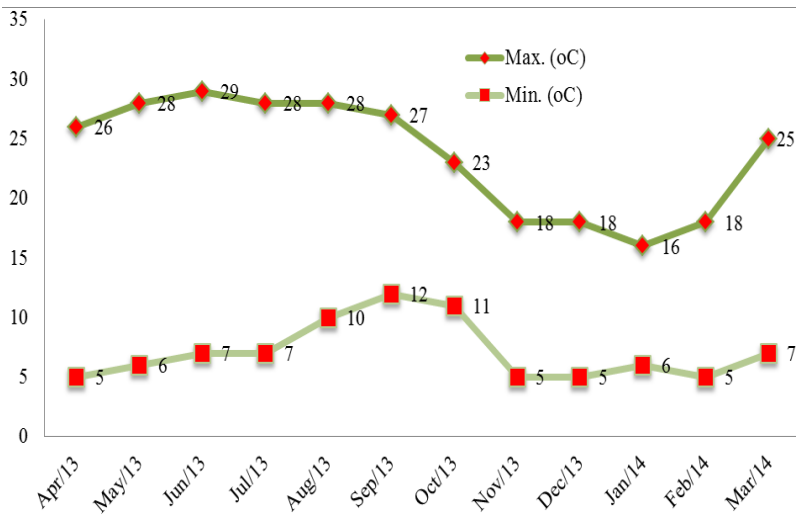

Fig. 1. Graphical presentation of monthly maximum and minimum temperature during April-2013 to March 2014.

$\mathrm{pH}$ and organic matter content), B concentration, moisture, and plant species (Welch et al., 1991). Boron absorption by plant roots is closely related to $\mathrm{pH}$ and $\mathrm{B}$ concentration in the soil solution; and is probably a non-metabolic process (Brown and $\mathrm{Hu}, 1998$ ). The soil of Sikkim is acidic in nature having high organic matter content and poor in B content. There is no information is available effect of boron nutrition on large cardamom. Keeping these in view the present study was undertaken to find out the effect of boron on growth, nutrition and fertility status of large cardamom in Sikkim Himalaya.

\section{MATERIALS AND METHODS}

Field experiment was conducted during 2013-2014 at Indian Cardamom Research Institute, Regional Research Station, Spices Board research farm Kabi, North Sikkim ( altitude $1567 \mathrm{~m}$ amsl; latitude $27^{\circ} 24^{\prime}$ $21.79^{\prime \prime} \mathrm{N}$; longitude $\left.88^{\circ} 37^{\prime} 12.23^{\prime \prime} \mathrm{E}\right)$. The annual rainfall received $4654 \mathrm{~mm}$ (Fig. 1) with 171 numbers of rainy days and maximum $29.2{ }^{\circ} \mathrm{C}$ and minimum temperature $5.4{ }^{\circ} \mathrm{C}$ (Fig. 2) recorded during the experimental period. Soil of experimental field was clay loam and had soil pH 4.7 (1: 2.5 soil and water ratio), $245.5 \mathrm{~kg} \mathrm{ha}^{-1}$ alkaline permanganate oxidizable $\mathrm{N}$, $28.30 \mathrm{~kg}$ ha ${ }^{-1}$ Brays $\mathrm{P}_{1}, 199.3 \mathrm{~kg} 1 \mathrm{~N}$ ammonium

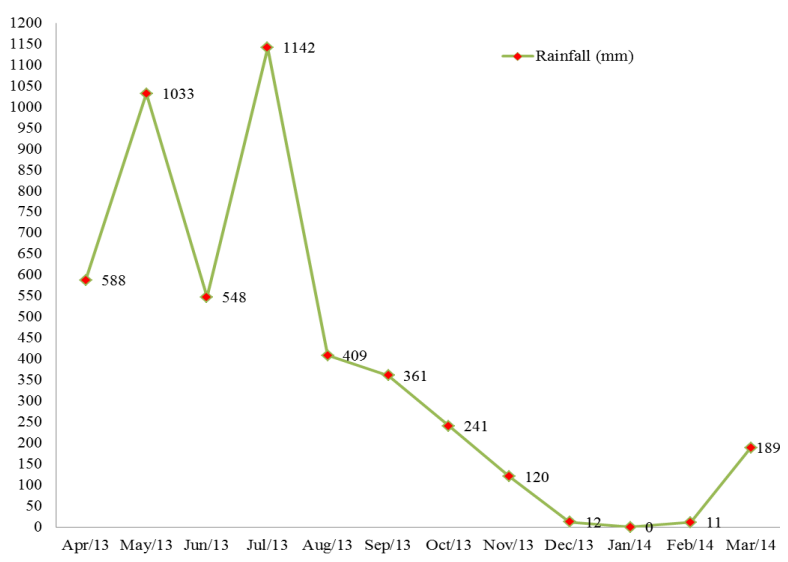

Fig. 2. Graphical presentation of monthly average rainfall received during April-2013 to March 2014. acetate exchangeable K, 0.096 ppm hot water boron and $1.98 \%$ organic carbon. The experiment was laid out in Randomized Block Design (RBD) comprising seven treatments viz., soil application of borax @ 2.5 $\mathrm{kg} \mathrm{ha}^{-1}\left(\mathrm{~T}_{1}\right)$, soil application of borax@5.0 kg ha-1 $\left(\mathrm{T}_{2}\right)$, foliar application of borax@0.25\% $\left(\mathrm{T}_{3}\right)$, foliar application of borax@0.5\% ( $\left.\mathrm{T}_{4}\right)$, foliar application of borax@0.25\% \% $\mathrm{T}_{1}\left(\mathrm{~T}_{5}\right)$, foliar application of borax@0.5\%+T $\left(\mathrm{T}_{6}\right)$ and Control $\left(\mathrm{T}_{7}\right)$. All the treatments were replicated thrice during both the years. Large cardamom cultivar Sawney was selected and planted with the spacing of $1.5 \mathrm{~m} \times 1.5 \mathrm{~m}$ during July 2011. Treatments were imposed as per the technical programme during April on words after the receipt of summer showers. The growth observations were recorded as per the standard procedures in two times in year i.e. September 2013 and March 2014. The plant samples collected were ground into fine powder and pass through a $40 \mathrm{~mm}$ mesh sieve and used for chemical analysis to find out the nutrient content in plants. Similarly, the composite soil samples were collected from $0-15 \mathrm{~cm}$ soil profile for analysis of nutrient content. The soil samples were air-dried, ground and passed through $100 \mathrm{~mm}$ mesh sieve and were analyzed. Standard laboratory methods were followed for analyzing the plant and soil sample to find out the nutrient content. The soil and plant samples were analysis at Division of Agronomy and Soil Science, Indian Cardamom Research Institute, Spices Board, Myladumpara, Kerala.

\section{RESULTS AND DISCUSSION}

Growth Parameters of Large Cardamom: Critical appraisal of data revealed that, application of boron significantly affected the immature, mature tillers and vegetative buds (Table 1). Among the boron treatments, foliar application of Borax @0.5\%+soil application of Borax@2.5 kg ha ${ }^{-1}$ recorded the maximum values of immature tillers per clump (2.98 and 3.95) and mature tillers per clump (2.99 and 3.11) during both September, 2013 and March, 2014 and vegetative buds per clump (2.90). It might be due to positive role of boron in meristamatic tissue development, whether these are root tips, tips of upper plant parts. Another possible reason may be, the better translocation of sugars in the form of sugar borate, which inhibits the production of phenolic acid and phenolic compounds, thus checked the necrosis.

Nutrient Content in Large Cardamom Leaf: Data present in (Tables 2 and 3) clearly showed that boron application enhanced the nutrient content in leaf of large cardamom. However, its effect was statistically non-significant on $\mathrm{K}, \mathrm{S}, \mathrm{Ca}, \mathrm{Zn}, \mathrm{Cu}, \mathrm{Mn}$ and $\mathrm{Fe}$ content and significant on $\mathrm{N}, \mathrm{P}, \mathrm{Mg}$ and $\mathrm{B}$ content in leaf. Among the treatments imposed to large cardamom, foliar application of Borax@0.5\%+soil application of Borax@2.5 kg ha ${ }^{-1}$ resulted in maximum $\mathrm{N}$ content $(2.59 \%)$, P content $(0.18 \%), \mathrm{Mg}(0.39 \%)$ and boron 
content $(15.45 \mathrm{ppm})$. This might be due to positive interaction of boron with $\mathrm{N}$ and $\mathrm{P}$ which facilitated the better translocation of these nutrients. Increasing supply of B increased the accumulation of B in roots and shoots were also reported in barley by (Nable et al., 1990; Akram et al., 2006).

Fertility status of experimental site at Kabi, North Sikkim: Perusal of data showed that soil fertility status, of boron nutrition failed to affect the soil fertility status except boron content in soil (Table 4). Among the boron treatments, foliar application of Borax@0.5\%+soil application of Borax@2.5 kg ha ${ }^{-1}$ recorded the maximum value of boron $(0.257 \mathrm{ppm})$. This was 62.25 per cent higher than the control. This might be due to soil application of borax coupled with foliar application simultaneously, which may enhance the soil solution boron.

\section{Conclusion}

On the basis of above study it is concluded that foliar application of Borax@0.5\%+soil application of Borax @2.5 kg ha ${ }^{-1}$ may be recommended to achieve the higher productivity of large cardamom in Sikkim, Himalaya.

\section{ACKNOWLEDGEMENT}

Authors are thankful to the Director (Research), Indian Cardamom Research Institute, Spices Board, Myladumpara, Kerala for providing necessary facilities for analysis of soil and plant samples.

\section{REFERENCES}

Akram, M.S., Ali, Q., Athar, H. and Bhatti, A.S. (2006). Ion uptake and distribution in Panicum antidotale Retz. under salt stress. Pakistan Journal of Botany, 38:16611669.

Brown, P.H. and Hu, H. (1998). Boron mobility and consequent management. In: Better Crops, 82: 28-31.

Chakraborty, A.K. and Das, D.K. (2000). Interaction between boron and sulphur on different quality parameters of rape (Brassica campestris L.). Research on Crops, 1 (3): 326-329.

Deka, T.N., Gudade, B.A., Saju, K.A, Vijayan, A.K. and Chhetri, P. (2014). Foraging behavior of Bumble bee (Bombus breviceps) in large cardamom (Amomum subulatum Roxb.) at Dzongu, North Sikkim. Ecology, Environment and Conservation, 20(4): 197-199.

Gudade, B.A., Chhetri, P., Gupta, U. and Deka, T.N. (2013b). Establishment of large cardamom (Amomum subulatum Roxb.) sucker nursery at Sikkim. Popular Kheti, 1(3): 1-3.

Gudade, B.A., Chhetri, P., Gupta, U. and Harsha, K.N. (2013a). More large cardamom under Alnus trees. Indian Horticulture, 58(2): 19-20.

Gudade, B.A., Harsha, K.N., Vijayan, A.K., Chhetri, P., Deka, T.N., Babu, Subhash and Singh, Raghavendra (2015). Effect of Foliar Application of $\mathrm{Zn}, \mathrm{Mn}, \mathrm{Mg}$ on Growth and Nutrient Content in Large Cardamom (Amomum subulatum Roxb.) at Sikkim. Environment and Ecology. 33(4A): 1770-1773.

Loomis, W.D. and Durst, R.W. (1992). Chemistry and biology of boron. Biofactors, 3: 229-239.

Mandal, M., Roy, N.R., Mazumdar, D. and Das, D.K. (2009). Effect of different sources of boron on its maintenance in soil in relation to rape (Brassica campestris L.). Archives of Agronomy and Soil Science, 55(3): 247253.

Miwa, K. and Fujiwara, T. (2010). Boron transport in plants: co-ordinated regulation of transporters. Annals of Botany, 105: 1103-1108.

Nable, R.O., Lance, R.C.M. and Cartwright, B. (1990). Uptake of boron and silicon by barley genotypes with differing susceptibilities to boron toxicity. Annals of Botany, 66: 83-90.

Prasad, R. (2012). Fertilizers and manures. Current Science, 102(6): 894-898.

Wajahat, N., Perveen, S. and Saleem, I. (2006). Status of micronutrients in soils of district Bhimber (Azad Jammu and Kashmir). Journal of Agriculture and Biological Sciences, 1(2): 35-40.

Welch, R.M., Allaway, W.H., House, W.A. and Kubota, J. (1991). Geographic distribution of trace element problems. In: Micronutrients in agriculture, J. J. Mortvedt (Ed.) 2nd edition, Madison, WI, U.S.A. pp 31-57. 